\title{
Hubungan Kemampuan Berpikir Kreatif Aspek Kelancaran (Fluency) antara Jawaban Essay dan Pembuatan Poster pada Pembelajaran Berbantuan Media Animasi
}

Diterima 27 Maret 2018, Disetujui 27 Maret 2018, Dipublikasikan April 2018

\author{
A Muttaqiin ${ }^{1, a)}$, D Machmudin ${ }^{2}$, and Y Sanjaya ${ }^{2}$ \\ ${ }^{1}$ Program Studi Pendidikan Ilmu Pengetahuan Alam, Universitas Negeri Padang, Jl. \\ Prof. Dr. Hamka, Padang, Indonesia \\ ${ }^{2}$ Departemen Pendidikan Biologi, Universitas Pendidikan Indonesia, J1. Dr.Setiabudi \\ No. 229, Bandung 40154, Indonesia \\ ${ }^{\text {a)} E-m a i l: ~ m u t t a q i i n . a @ f m i p a . u n p . a c . i d ~}$
}

\begin{abstract}
Abstrak. Penelitian ini bertujuan untuk menganalisis hubungan antara kemampuan berpikir kreatif siswa aspek kelancaran (fluency) yang diukur dengan soal essay dan tugas pembuatan poster. Data dijaring dari 33 siswa di salah satu SMA di Kota Cimahi, Jawa Barat. Berdasarkan hasil perhitungan statistik, diperoleh informasi bahwa tidak ada hubungan yang signifikan antara kemampuan berpikir kreatif siswa aspek kelancaran (fluency) yang diukur dengan soal essay dan tugas pembuatan poster. Hal ini menunjukkan bahwa kemampuan yang baik dalam menjawab soal-soal berpikir kreatif tidak membuat siswa baik juga dalam membuat poster.
\end{abstract}

Kata kunci: berpikir kreatif, media animasi, poster

\section{Pendahuluan}

Salah satu penekanan pembelajaran pada abad 21 adalah dengan melakukan pengembangan kemampuan berpikir tingkat tinggi (Pacific Policy Research Center, 2010). Dengan demikian, setiap negara akan menyesuaikan sistem pendidikan sesuai dengan tuntutan yang saat ini sedang berkembang. Hal ini akan membantu siswa untuk memiliki keterampilan-keterampilan yang nantinya dapat dijadikan bekal untuk menghadapi berbagai permasalahan dan tantangan di kehidupan nyata. Kemampuan berpikir tinggi perlu dibiasakan karena memiliki peranan yang penting dalam membantu siswa memperoleh informasi secara akurat (King, Goodson, \& Rohani, 1998).

Karena pentingnya kemampuan berpikir tingkat tinggi ini, maka sekolah-sekolah perlu mengembangkannya dengan berbagai cara. Sekolah-sekolah harus merangsang siswa untuk menggunakan kemampuan berpikir tingkat tinggi agar siswa senantiasa terbiasa dan mampu terbiasa dengan cara berpikir seperti ini (Miri, David, \& Uri, 2007). Dengan demikian, perangsangan siswa untuk berpikir tingkat tinggi, dalam hal ini berpikir kreatif, perlu diterapkan secara efektif misalnya dengan mengajarkan siswa tentang cara menyelesaikan masalah atau mengambil keputusan terhadap suatu masalah (Five, 1993).

Saat ini, sekolah-sekolah di Indonesia masih kurang membiasakan siswa dalam berpikir tingkat tinggi. Berpikir kreatif adalah salah satu kemampuan yang mestinya dilatihkan selama pembelajaran berlangsung untuk menunjang kemampuan siswa dalam memecahkan masalah di kehidupan nyata. Untuk itu, penelitian sebelumnya telah dilakukan dalam upaya untuk meningkatkan berpikir kreatif dengan menggunakan pembelajaran dengan bantuan media animasi. Untuk mengetahui lebih lanjut mengenai profil kamampuan berpikir kreatif siswa, khususnya pada aspek kelancaran (Fluency), penelitian ini akan menganalisis hubungan antara kemampuan berpikir kreatif aspek kelancaran yang dijaring oleh soal uraian dan penugasan poster. 
Sekretariat: Jurusan Pendidikan IPA, Fakultas Matematika dan Ilmu Pengetahuan Alam, Universitas Negeri Padang - Jl. Prof. Dr. Hamka, Air Tawar Padang, Sumatera Barat

E-mail :prodiipa16@gmail.com, Halaman website : http://www.semesta.ppj.unp.ac.id/index.php/semesta.

Jurnal SEMESTA, Vol.01, No.01, 2017 pp. 1-5

\section{Metode Penelitian}

Populasi dari penelitian ini merupakan peserta didik kelas XI dari salah satu SMA di Kota Cimahi. Sampel dipilih dengan purposive sampling kerena membutuhkan kelas yang homogen, yakni memilih kelas dengan kemampuan anak yang cenderung sama atau tidak terlalu berbeda berdasarkan nilai yang telah diperoleh sebelumnya.

Penelitian ini bertujuan untuk melihat hubungan antara kemampuan berpikir kreatif aspek kelancaran (fluency) yang dijaring oleh dua bentuk instrumen yang berbeda. Instrumen yang dimaksud berbentuk soal uraian (essay) dan produk berupa poster. Data diperoleh dari hasil postes yang diberikan pada kelas eksperimen yang diberi perlakuan. Data yang diperoleh terdiri dari 2 jenis, yakni kemampuan berpikir kreatif dalam mendeskripsikan solusi-solusi dari berbagai permasalahan yang diberikan dan kemampuan berpikir kreatif dalam menghasilkan produk berupa poster.

Untuk melihat hubungan antara kedua jenis data yang diperoleh, dilakukan uji korelasi Pearson (jika data terdistribusi normal dan homogen) atau uji Spearman (jika data terdistribusi normal, namun tidak homogen, dan sebaliknya). Tingkat kepercayaan yang digunakan dalam pengujian statistik (uji korelasi) ini adalah 0,05. Dengan demikian, akan diperoleh hasil berupa hasil perhitungan kuantitatif berdasarkan data yang ada.

\section{Hasil dan Pembahasan}

\subsection{Hasil}

Untuk memperoleh data yang diharapkan, dilakukan posttest pada kelas perlakuan untuk memperoleh nilai kemampuan berpikir kreatif dan pemberian tugas poster. Indikator didasarkan pada indikator berpikir kreatif yang dikembangkan oleh Munandar (1992). Hasil perolehan kemampuan berpikir kreatif baik kemampuan yang diukur oleh soal uraian dan poster dapat dilihat pada Gambar 1. Secara umum, diketahui bahwa perolehan kemampuan berpikir kreatif siswa yang dijaring oleh soal uraian lebih baik dibandingkan dengan nilai poster.

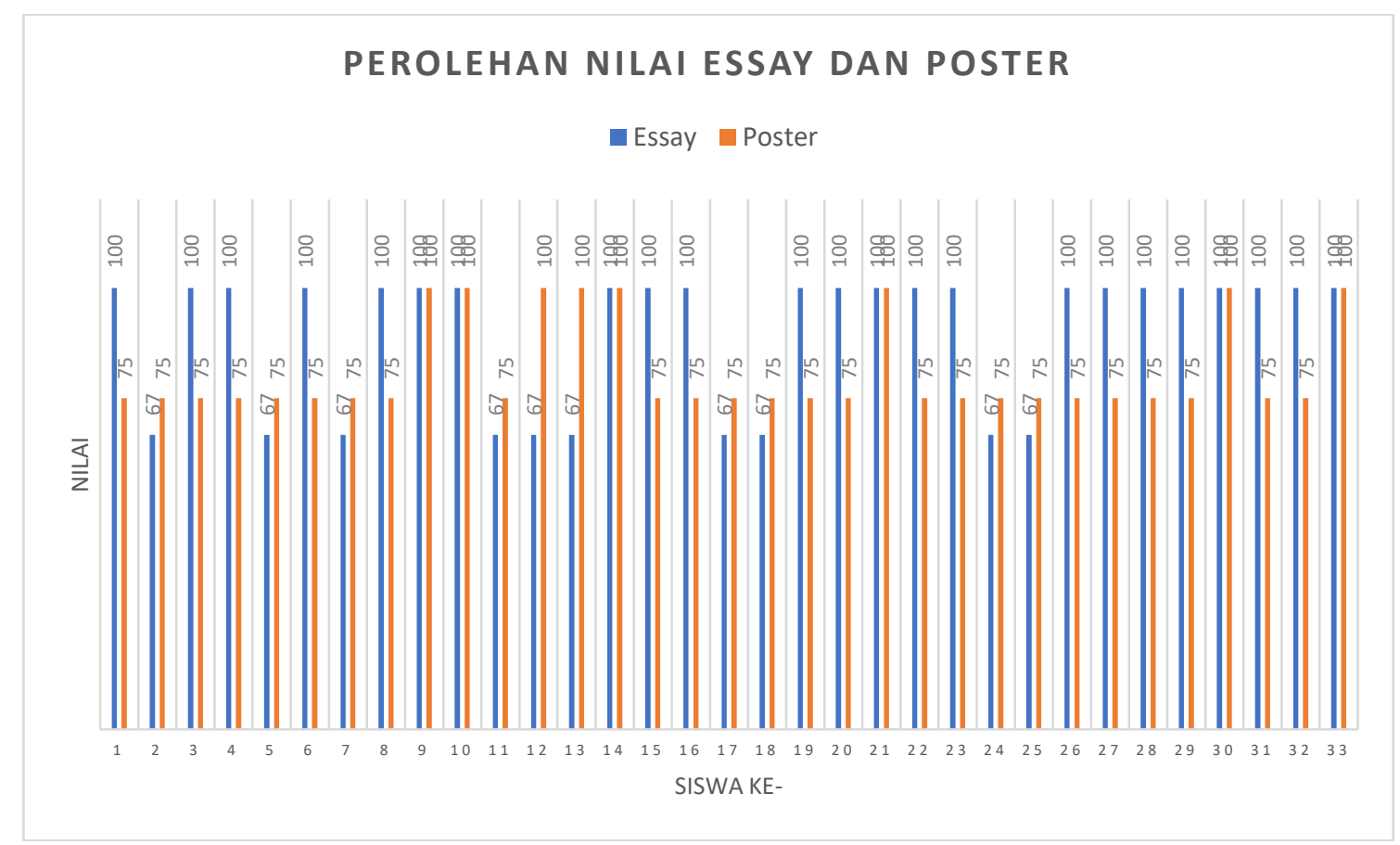

Gambar 1 Diagram Perolehan Nilai Kemampuan berpikir kreatif pada aspek berpikir lancer yang dijaring oleh soal Essay dan penugasan Poster 
Sekretariat: Jurusan Pendidikan IPA, Fakultas Matematika dan Ilmu Pengetahuan Alam, Universitas Negeri Padang - Jl. Prof. Dr. Hamka, Air Tawar Padang, Sumatera Barat

E-mail :prodiipa16@gmail.com, Halaman website : http://www.semesta.ppj.unp.ac.id/index.php/semesta.

Jurnal SEMESTA, Vol.01, No.01, 2017 pp. 1-5

Nilai maksimal yang ditentukan dalam menjaring kemampuan berpikir kreatif ini adalah 100 , sedangkan nilai minimalnya adalah 0 . Secara umum, perolehan rata-rata nilai kemampuan berpikir kreatif siswa pada aspek fluency yang dijaring dengan soal uraian lebih tinggi dibandingkan dengan kemampuan berpikir kreatif yang dijaring oleh poster (lihat Tabel 1). Selisih antara dua data tersebut adalah 8,84 . Siswa dengan perolehan yang lebih tinggi pada soal essay dibandingkan poster adalah 17 siswa, sedangkan siswa dengan peroleh nilai poster yang lebih tinggi adalah sebanyak 10 siswa dan sebanyak 6 siswa memiliki perolehan nilai yang sama, baik nilai essay ataupun nilai posternya.

Table 1 Rata-rata Perolehan Nilai Berpikir Kreatif dengan Instrumen Soal Essay dan Poster

\begin{tabular}{cc}
\hline Essay & Poster \\
\hline 89,90 & 81,06 \\
\hline
\end{tabular}

Untuk melihat hubungan apakah nilai kemapuan berpikir kreatif pada aspek fluencyyang tinggi dalam soal uraian akan memiliki nilai yang tinggi pula pada kemampuan berpikir kreatif pada aspek fluencydalam membuat poster, dilakukan pengujian statistik dengan uji Spearman. Hal ini dikarenakan data tidak berdistribusi normal dan data homogen sehingga dilakukan uji korelasi non-parametrik. Hasil pengujian secara rinci dapat dilihat pada Tabel 2.

Tabel 2. Hasil Pengujian Statistik: Uji Normalitas, Uji Homogenitas dan Uji Korelasi.

\begin{tabular}{lcccc}
\hline & & Statistic & df & Sig. (2-tailed) \\
\hline Spahiro-Wilk & Essay & 0.439 & 33 & 0.000 \\
& Poster & 0.469 & 33 & 0.000 \\
Levene & & 0.630 & 31 & 0.433 \\
Spearman & & 0.065 & 33 & 0.718 \\
\hline
\end{tabular}

\subsection{Pembahasan}

Selama pembelajaran, dalam upaya untuk meningkatkan kemampuan berpikir kreatif siswa pada aspek fluency, media animasi digunakan untuk meningkatkan motivasi siswa dalam belajar sehingga meningkat pula kemampuan berpikir kreatifnya. Media ini akan cukup mempengaruhi siswa dalam ketertarikan belajar (Rustaman, 2005). Siswa yang melaksanakan pembelajaran dengan media animasi akan sedikit banyak mempengaruhi caranya berpikir, sehingga diharapkan terdapat peningkatan dalam kemampuan berpikir kreatifnya. Dalam mengungkapkan gagasan-gagasan kreatifnya, siswa memiliki caranya sendiri berdasarkan minat dan pengalamannya.

Hasil penelitian menunjukkan bahwa siswa memiliki perolehan kemampuan berpikir kreatif pada aspek fluency yang beragam jika dilihat secara keseluruhan. Pada siswa yang posttestnya baik, belum tentu memiliki nilai yang baik pula pada nilai posternya. Gambar 1 menunjukkan bahwa sebagian besar siswa tidak konsisten dalam mendapatkan kedua nilai. Namun, nilai yang diperoleh cenderung baik, yang ditunjukkan dengan perolehan nilai minimal 67 dan tidak ada yang kurang dari nilai tersebut. Adanya perbedaan ini dapat diakibatkan karena bakat kreatif setiap orang tidaklah seragam (Munandar, 1992) sehingga nilai yang diperoleh akan sangat beragam.

Lebih lanjut, hasil pengujian statistik menunjukkan bahwa tidak terdapat hubungan yang signifikan antara kemampuan berpikir pada aspek fluency yang dijaring oleh soal essay atau penugasan poster. Artinya, siswa dengan nilai yang baik pada soal essay belum tentu memiliki nilai poster yang baik. Dengan kata lain, kemampuan berpikir kreatif pada aspek fluency yang baik saat dituangkan dalam bentuk tulisan tidak selamanya selaras dengan berpikir kreatif yang dituangkan dalam bentuk karya/ produk.

Dalam berpikir kreatif, siswa diberi kesempatan untuk berpikir bebas tanpa beban (Saleh, 2008), sehingga siswa dapat mengoptimalkan bagaimana cara mereka berpikir dalam menyelesaikan masalah 
Jurnal SEMESTA, Vol.01, No.01, 2017 pp. 1-5

yang ada di sekitarnya. Tidak adanya hubungan dari kedua variabel ini menunjukkan bahwa cara siswa mengungkapkan gagasan adalah salah satu komponen yang perlu diperhatikan. Siswa yang senang menulis akan lebih mudah mengungkapkan gagasan melalui tulisan, namun sebaliknya bagi siswa yang kurang menyukai tulisan, misalnya lebih menyukai media gambar, akan lebih cenderung menonjol dalam karya/ produk gambar seperti poster dalam menyampaikan gagasan-gagasan kreatifnya. Senada dengan Supriadi (1994) yang menyatakan bahwa kemampuan berpikir siswa tidaklah sama satu sama lain. Hal ini menunjukkan bahwa hasil pemikiran atau gagasan setiap siswa akan berbeda-beda. Gambar 2 menunjukkan beberapa karya/ hasil poster yang dibuat oleh siswa terkait dengan materi sistem pernapasan pada manusia.
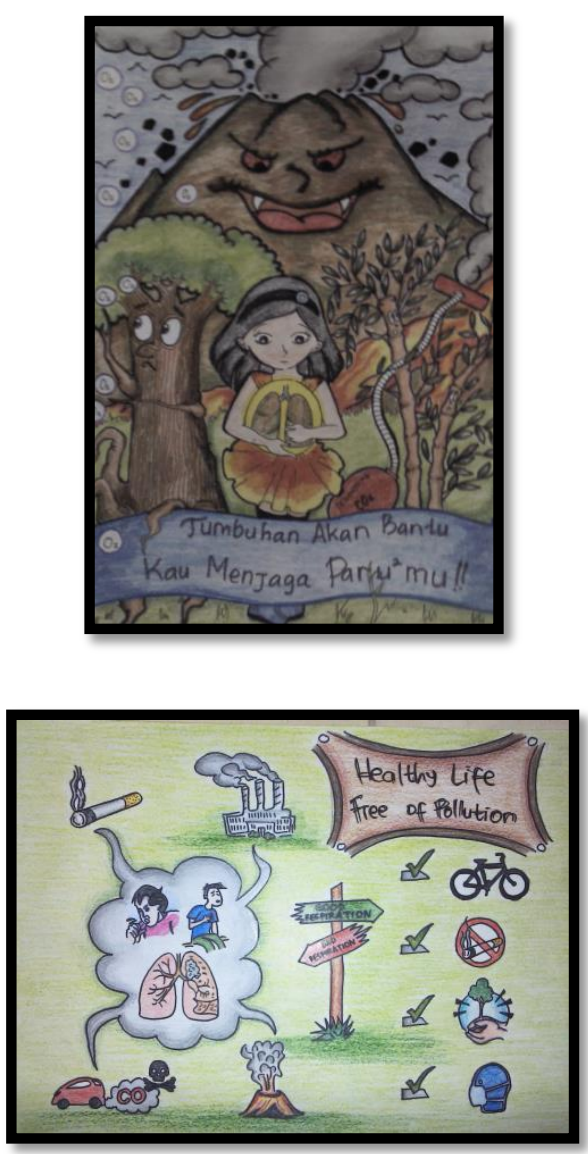
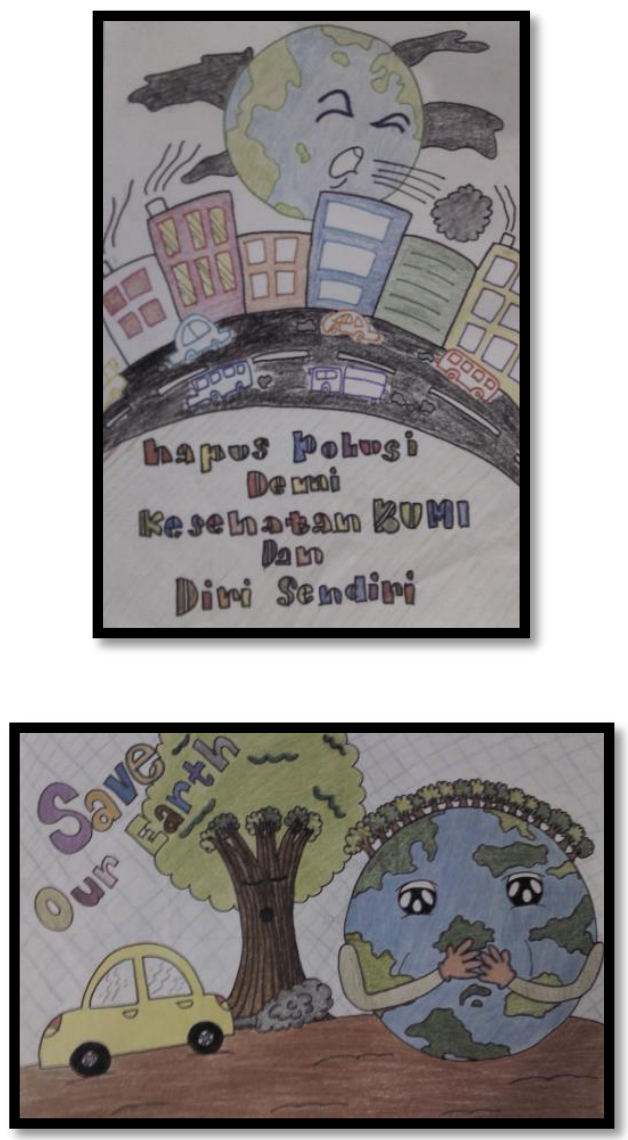

Gambar 2 Beberapa Hasil Penugasan Poster dari Beberapa Siswa (Sumber: Dokumentasi Pribadi)

\section{Kesimpulan}

Setiap siswa adalah unik dan memiliki karakternya masing-masing, baik dalam berperilaku ataupun berpikir. Cara siswa untuk menujukkan kreatifitasnya sangatlah beragam, kita dapat mengukur dengan alat yang sama, namun penggunaan alat ukur yang beragam akan memberikan ruang yang lebih terbuka untuk siswa berkreasi dalam mengmbangkan kemampuan berpikir kreatifnya. Tidak terdapatnya hubungan antara kemampuan berpikir kreatif yang dijaring menggunakan soal essay dengan poster menunjukkan bahwa siswa memiliki cara atau jalan masing-masing untuk mengungkapkan permikiran terbaiknya. 


\section{Jurnal SEMESTA Pendidikan IPA e-ISSN 2598-1951}

Sekretariat: Jurusan Pendidikan IPA, Fakultas Matematika dan Ilmu Pengetahuan Alam, Universitas Negeri Padang - Jl. Prof. Dr. Hamka, Air Tawar Padang, Sumatera Barat

E-mail :prodiipa16@gmail.com, Halaman website : http://www.semesta.ppj.unp.ac.id/index.php/semesta.

Jurnal SEMESTA, Vol.01, No.01, 2017 pp. 1-5

\section{Ucapan Terima Kasih}

Ucapan terima kasih saya ucapkan kepada Drs. Dadang Machmudin, M.Si. dan Yayan Sanjaya, Ph.D, yang telah membantu proses penyusunan artikel ini.

\section{Daftar Pustaka}

Five, C. (1993). Teaching Higher-Order Thinking. Educational Leadership, 50(7), 53-61.

King, F. J., Goodson, L., \& Rohani, F. (1998). Higher Order Thinking Skills. Publication of the Educational Services Program, Now Known as the Center for Advancement of Learning and Assessment. Obtido de: Www.cala.fsu.edu, 1-176. Retrieved from http://www.cala.fsu.edu/files/higher_order_thinking_skills.pdf

Miri, B., David, B. C., \& Uri, Z. (2007). Purposely teaching for the promotion of higher-order thinking skills: A case of critical thinking. Research in Science Education, 37(4), 353-369. https://doi.org/10.1007/s11165-006-9029-2

Munandar, U. (1992). Mengembangkan Bakat dan Kreativitas Anak Sekolah. Jakarta: PT. Grasindo. Pacific Policy Research Center. (2010). 21 st Century Skills for Students and Teachers. Research \& Evaluation, 1-25. Retrieved from www.ksbe.edu/spi

Rustaman, N. (2005). Strategi Belajar Mengajar Biologi. Malang: UM Press.

Saleh, A. (2008). Kreatif Mengajar dengan Mindmap. Bandung: Tinta Emas Publishing.

Supriadi, D. (1994). Kreativitas, Kebudayaan, Dan Perkembangan IPTEK. Bandung: Alfabeta. 